ББК 63.4

$$
\begin{gathered}
\text { Организация конференции и издание материалов проведены } \\
\text { при финансовой поддержке Российского фонда фундаментальных исследований, } \\
\text { проект № 19-09-20008 }
\end{gathered}
$$

Утверждено к печати Ученым советом ИИМК РАН

Редакционная коллегия тома II: А. В. Поляков, Е. С. Ткач (отв. редакторы), М. Т. Кашуба, Л. Б. Кирчо, Е. А. Черлёнок, В. Я. Стёганцева, А. И. Климушина

Рещензенты: д. и. н. Л. Б. Вишняцкий, д. и. н. А. А. Выборнов

Программный комитет конференции: академик РАН, д. и. н., проф. М. Б. Пиотровский (Государственный Эрмитаж, почетный председатель); д. и. н. В. А. Лапшин (ИИМК РАН, председатель); д. и. н. А. В. Головнёв (МАЭ РАН, сопредседатель); д. и. н. В. А. Дергачёв (Высшая антропологическая школа, Молдова, сопредседатель); д. и. н. И. Ф. Попова (ИВР РАН, сопредседатель); академик АН Республики Узбекистан, д. и. н., проф. Э. В. Ртвеладзе (сопредседатель); к. и. н. А. В. Поляков (ИИМК РАН, зам. председателя); к. и. н. В. А. Алёкшин (ИИМК РАН, зам. председателя); д. и. н. Ю. Е. Берёзкин (МАЭ РАН); Dr., Prof. Н. Бороффка

(Германский археологический институт, Германия); В. С. Бочкарёв (ИИМК РАН);

Dr. Э. Кайзер (Свободный университет Берлина, Германия); к. и. н. М. Т. Кашуба (ИИМК РАН); д. и. н. Л. Б. Кирчо (ИИМК РАН); к. и. н. А. В. Кияшко (Южный федеральный университет); к. и. н. П. Ф. Кузнецов (СГСПУ); к. и. н. Н. М. Малов (СНИГУ); к. и. н. В. П. Никоноров (ИИМК РАН); Ю. Ю. Пиотровский (Государственный Эрмитаж); д. и. н., проф. Д. Г. Савинов (Институт истории СПбГУ); к. и. н. В. Н. Седых (Институт истории СПбГУ); к. и. н. Н. Н. Скакун (ИИМК РАН); к. и. н. Н. Ф. Соловьёва (ИИМК РАН); к. и. н. А. И. Торгоев (Государственный Эрмитаж); к. и. н. Е. А. Черлёнок (Институт истории СПбГУ)

Организационный комитет конференции: к. и. н. А. В. Поляков (ИИМК РАН, председатель); к. и. н. В. А. Алёкшин (ИИМК РАН, зам. председателя); В. С. Бочкарёв (ИИМК РАН); к. и. н. М. Т. Кашуба (ИИМК РАН); д. и. н. Л. Б. Кирчо (ИИМК РАН);

А. И. Климушина (ИИМК РАН, отв. секретарь); к. и. н. В. П. Никоноров (ИИМК РАН); Ю. Ю. Пиотровский (Государственный Эрмитаж); В. Я. Стеганцева (ИИМК РАН); В. В. Терёхина (ИИМК РАН, МАЭ РАН, отв. секретарь); к. и. н. Е. С. Ткач (ИИМК РАН); И. Ж. Тутаева (Государственный Эрмитаж); к. и. н. Е. А. Черлёнок (Институт истории СПбГУ)

Древности Восточной Европы, Центральной Азии и Южной Сибири в контексте связей и взаимодействий в евразийском культурном пространстве (новые данные и концепции): Материалы Международной конференции, 18-22 ноября 2019 г., Санкт-Петербург. Т. ІІ. Связи, контакты и взаимодействия древних культур Северной Евразии и цивилизаций Востока в эпоху палеометалла (IV-I тыс. до н. э.). К 80-летию со дня рождения выдающегося археолога В. С. Бочкарёва. - СПб.: ИИМК РАН, Невская Типография, 2019. - 287 с.

ISBN 978-5-907053-35-9

DOI 10.31600/978-5-907053-35-9 


\title{
CHRONOLOGY OF THE SINTASHTA CULTURE WITHIN THE PERIODIZATION SYSTEM OF P. REINECKE
}

\author{
Stanislav A. Grigor'yev \\ Institute of History and Archeology of the Ural Branch of RAS, Chelyabinsk, Russia
}

Keywords: chronology, Sintashta culture, periodization by P. Reinecke, Central and Eastern Europe.

The chronological system of $P$. Reinecke is a convenient tool for synchronizing the Eurasian cultures, including that of Sintashta. The upper border of Sintashta is determined by the time of the penetration of Seyma tradition into Europe during phase A2b (the next phase A2c includes the Pokrovsk, Petrovka and Alakul sites). European dendrochronology allows us to date this period to the second half of the $17^{\text {th }}$ century $\mathrm{BC}$, and it is consistent with the Mycenaean chronology, but is younger than radiocarbon dates (ca $1770 \mathrm{BC}$ ). Determination of the lower border is rather problematic. Thanks to the Central European impulses at the formation of Babino and Abashevo cultures, the latter have many parallels in Europe. Their maximum number falls into phases A1b-A2a. But the only period of their real coexistence is phase A1c. Within the radiocarbon chronology, the lower border of the culture falls into the $20^{\text {th }}$ century BC, but on the basis of the Near Eastern parallels, it seems younger, i. e. about $19^{\text {th }} / 18^{\text {th }}$ centuries BC.

\section{КОМПЛЕКС МЕТАЛЛИЧЕСКИХ ИЗДЕЛИЙ ЭПОХИ ПОЗДНЕЙ БРОНЗЫ С ТЕРРИТОРИИ КУРГАННОЙ ГРУППЫ 6 ВОЙЦЕХОВСКОГО МОГИЛЬНИКА}

\author{
С. Д. Лысенко, С. С. Лысенко \\ Институт археологии НАН Украины, Киев, Украина
}

DOI: $10.31600 / 978-5-907053-35-9-59-62$

Ключевые слова: тиинецикий культурный круг, период финальной бронзы, белогрудовский горизонт, изделия из бронзы.

Войцеховский могильник является одним из ключевых памятников волынской группы комаровской культуры тшинецкого культурного круга. Могильник состоит из 17 курганных групп, объединяющих более 100 курганов (Лысенко, Лысенко 2011). Большинство исследованных на памятнике комплексов эпохи поздней бронзы относится к классическим горизонтам комаровской культуры (середина - третья четверть II тыс. до н. э.) (Лагодовська 1948; Лагодовська, Захарук 1956; Лысенко, Лысенко 2018); обнаружены также объекты периода финальной бронзы и раннего железного века (Лысенко, Лысенко 2017).

В 2013 г. на площади курганной группы 6, в пахотном слое, было зафиксировано 46 изделий из цветных металлов эпохи бронзы, скифского времени, черняховской культуры, древнерусского периода (значительную часть перечисленных изделий Фастовской археологической экспедиции передал краевед А. С. Абалмасов с указанием точного местонахождения). Коллекция артефактов эпохи бронзы включает 31 предмет, большинство из которых сильно фрагментированы: семь ножей, пять серпов, четыре кельта, три ножа-кинжала, фрагмент лезвия меча, четыре наконечника копий, псалий, фрагмент стержня булавки-жезла гордеевского типа, два браслета, фрагмент прута, два бронзовых слитка. Общая площадь распространения находок - около $500 \times 250$ м. Находки концентрируются двумя скоплениями.

Все находки могут быть разделены на две разновеликие группы: I - изделия, представляющие культурные влияния и/или непосредственные импорты из Карпато-Дунайского региона; II - изделия, связанные с местными культурами Северного Причерноморья. 

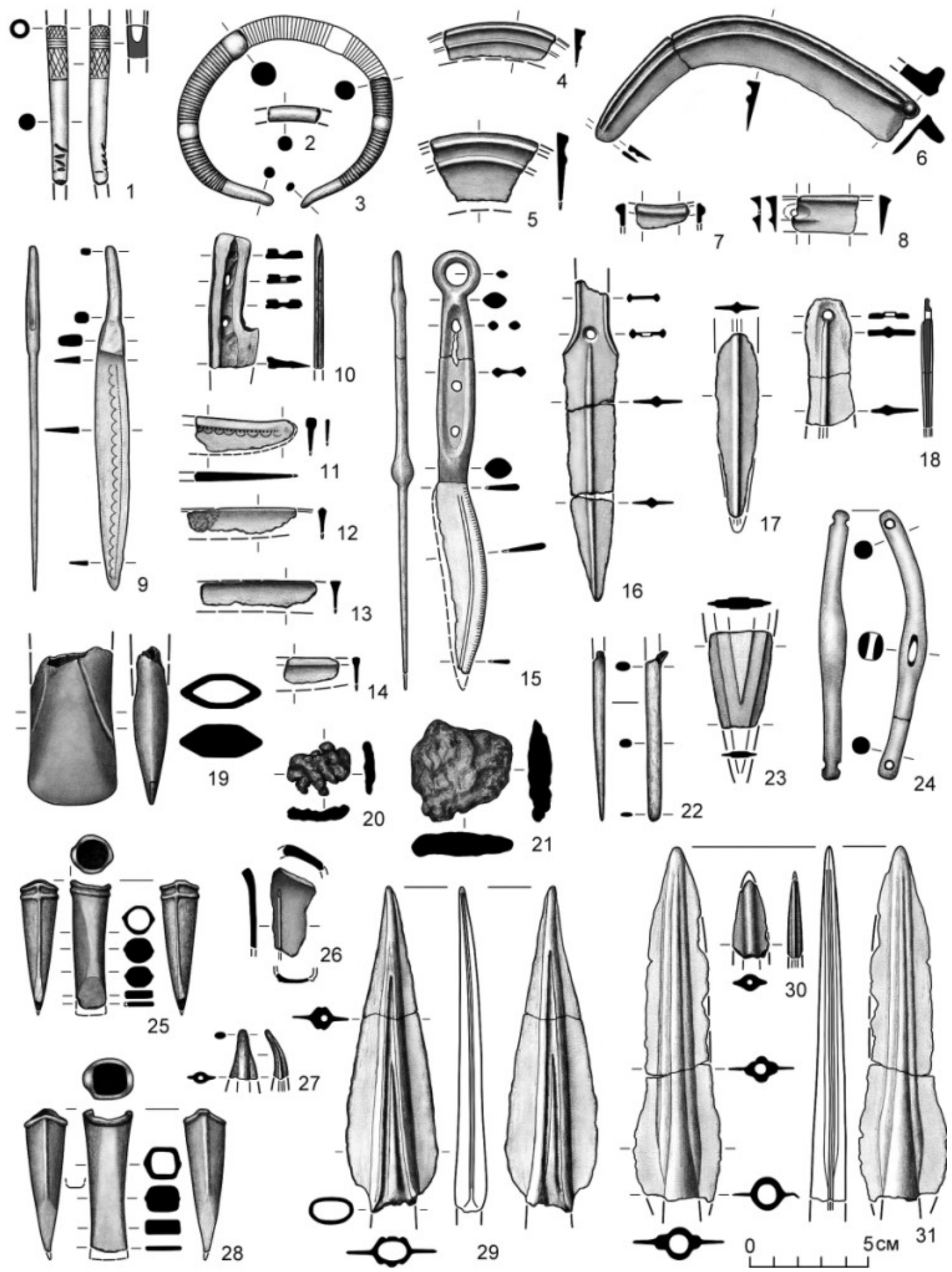

Рис. 1. Изделия из бронзы и их фрагменты с площади курганной группы 6 Войцеховского могильника: 1 - булавка-жезл; 2-3 - браслеты; 4-8 - серпы; 9-15 - ножи; 16-18 - ножикинжалы; 19, 25, 26, 28 - кельты; 20-21 - слитки; 22 - штырь; 23 - фрагмент лезвия меча; 24 - псалий; 27, 29-31 - наконечники копий 
К первой группе относятся: ножи однолезвийные (рис. 1, 9-15), серпы (рис. 1, 4-8), кельты (рис. 1, 19, 25, 26, 28), ножи-кинжалы двулезвийные (рис. 1, 16-18), фрагмент лезвия меча (рис. 1, 23), наконечники копий (рис. 1, 27, 29-31), браслеты (рис. 1, 2-3).

Все перечисленные предметы находят широкие аналогии в археологических культуpax Карпато-Подунавья периода BrD-HaA (Mozsolics 1967; Petrescu-Dîmbovița 1977; MüllerKarpe 1980; Дергачёв 2010; 2011). Серпы представлены типами Koszider верхнетисской (венгерской) серии и Heleșteni/Хелештень прикарпатско-трансильванской серии (Дергачёв, Бочкарёв 2002).

Цельнолитые однолезвийные ножи с плоской рукоятью с отверстиями под заклепки в Северном Причерноморье найдены в Галиции (Борщов; клад из Неделиск) (Крушельницька 1985: 83, рис. 25, 7-9), на Подолии (Гордеевка) (Berezanskaja, Kločko 1998: taf. 11, 6; $13,8 ; 24,1 ; 43,2)$; нож из кургана 31 Гордеевки имеет кольцевидное навершие (Berezanskaja, Kločko 1998: taf. 58, 1).

Вторая группа находок представлена псалием и фрагментом булавки-жезла.

Псалий (рис. 1, 24) стержневидный трехдырчатый. Ближайшие аналогии псалий находит среди костяных псалиев белогрудовского горизонта (Белогрудовский лес; Субботовское городище; Субботов, усадьба Б. Хмельницкого) (Тереножкин 1976: 85, 1, 3-5). Большая серия таких костяных псалиев и их заготовок происходит из жилища мастера-костореза на предместье городища белозёрской культуры Дикий Сад (Козленко 2018: рис. 2, 25-40).

Булавка-жезл гордеевского типа (рис. 1, 1), фрагмент стержня. Два таких изделия происходят из кургана 16 Гордеевки (Berezanskaja, Kločko 1998: taf. 27). Еще два депаспортизированы, хранятся в Национальном музее истории Украины (Лысенко и др. 2008).

Предположительно к рассматриваемому периоду относятся также бронзовый штырь (рис. 1, 22) и два небольших бронзовых слитка (рис. 1, 20-21). Такие слитки известны в ряде кладов эпохи поздней бронзы в Молдавии (Дергачёв 1975: 11, рис. 2, 8), Румынии (PetrescuDîmbovița 1977), Венгрии (Mozsolics 1967).

Нельзя исключать, что как минимум часть артефактов входила в состав распаханного клада/кладов (?), зарытого на площади могильника. Представленный условный комплекс, видимо, связан с очередным культурным импульсом из Карпато-Дунайского региона, совпадающим с усилением аридизации климата конца суббореала, и отражает период распада тшинецкого культурного круга в лесостепной части Восточной Волыни.

\section{Литература}

Дергачёв В. А. 1975. Бронзовые предметы XIII-VIII вв. до н. э. из Днестровско-Прутского междуречья. Кишинёв.

Дергачёв В. А. 2010. Топоры-кельты поздней бронзы Карпато-Подунавья. Вып. 1. Одноушковые кельты с арковидными фасками. Кишинёв.

Дергачёв В. А. 2011. Топоры-кельты поздней бронзы Карпато-Подунавья. Вып. 2. Кельты и серпы Нижнего Подунавья. Кишинёв.

Дергачёв В. А., Бочкарёв В. С. 2002. Металлические серпы поздней бронзы Восточной Европы. Кишинёв.

Козленко Р.А. 2018. Жилище мастера-костореза на предместье городища Дикий Сад // Емінак. № 3. Т. 3. С. 111-116.

Крушельницька Л. І. 1985. Взаємозв’язки населення Прикарпаття і Волині з племенами Східної і Центральної Європи (рубіж епох бронзи і заліза). Київ. 
Лагодовська О. Ф. 1948. Войцехівський могильник бронзової доби на Волині // Археологія. № II. C. 62-77.

Лагодовська О.Ф., Захарук Ю.М. 1956. Нові дослідження Войцехівського могильника // Археологічні пам'ятки УРСР. № VI. С. 69-74.

Лысенко С.Д., Лысенко С. С., Якубенко Е. А. 2008. Булавки-жезлы из собрания Национального музея истории Украины // Савинов Д. Г. (ред.). Случайные находки: хронология, атрибутация, историко-культурный контекст: Материалы тематич. науч. конф. (СанктПетербург, 16-19 декабря 2008 г.). СПб. С. 61-65.

Лысенко С. Д., Лысенко С. С. 2011. Вклад С. С. Гамченко в изучение памятников тшинецкого культурного круга // Платонова Н.И. (ред). История археологии: личности и школы: ММНК к 160-летию со дня рождения В. В. Хвойки (Киев, 05-08 октября 2010). СПб. C. 217-230.

Лысенко С. Д., Лысенко С. С. 2017. Курганоподобные возвышения с территории Войцеховского могильника (по результатам исследований 2013 г.) // Новое прошлое. № 4. С. 264-285.

Лысенко С. Д., Лысенко С. С. 2018. Курганная группа 3 Войцеховского могильник (по результатам исследований 2011-2012 гг.) // Синика В. С., Рабинович Р. А. (ред.). Древности. Исследования. Проблемы: Сб. ст. в честь 70-летия Н. П. Тельнова. Кишинёв; Тирасполь. C. $89-112$.

Тереножкин А. И. 1976. Киммерийцы. Киев.

Berezanskaja S. S., Klocko V. I. 1998. Das Graberfeld von Hordeevka. München.

Mozsolics A. 1967. Bronzefunde des Karpatenbeckens. Budapest.

Müller-Karpe H. 1980. Bronzezeit. München.

Petrescu-Dîmbovița M. 1977. Depozitele de bronzuri din România. București.

\section{COMPLEX OF METAL ARTIFACTS OF THE LATE BRONZE AGE IN THE TERRITORY OF THE ${ }^{\text {TH }}$ VOYTSEKHOVKA BARROW CEMETERY}

\section{Sergey D. Lysenko, Svetlana S. Lysenko \\ Institute of Archaeology of the National Academy of Sciences of Ukraine, Kiev, Ukraine}

Keywords: Trzciniec (Tshinetsky) cultural circle, Final Bronze Age, Belogrudovka horizon, bronze artifacts.

The Voytsekhovka cemetery is one of the most significant sites of the Komarovo culture of the Trzciniec (Tshinetsky) cultural circle. Most of its complexes of the Late Bronze Age studied earlier belong to the classical horizons of the Komarovo culture (middle to third quarter of the $2^{\text {nd }}$ mill. BC). In 2013, 46 items from non-ferrous metals of the Bronze Age Scythian period, Chernyakhov culture, and Early Russian period were found in the area of Barrow 6, in the arable layer. The collection of the Bronze Age artifacts includes 31 items, most of which are strongly fragmented: 7 knives, 5 sickles, 4 celts, 3 knives-daggers, a fragment of a sword blade, 4 spearheads, a cheek-piece, a fragment of a pin-rod of the Gordeyevo type, 2 bracelets, a rod fragment, 2 bronze ingots.

These artifacts can be dated to the BrD-HaA period. Perhaps they were part of a plowed-up hoard (hoards?) buried in the area of the cemetery. The conditional complex under study is apparently associated with some cultural impulse from the Carpathian-Danube region, which coincides with the aridization of climate in the end of the Subboreal period, and reflects the period of disintegration of the Trzciniec (Tshinetsky) cultural circle in the forest-steppe part of Eastern Volhynia. 